\title{
Article
}

\section{Synthesis of phytosterol esters catalyzed by immobilized lipase in organic media}

\author{
Zhenhua Jiang, Min Yu, Liwei Ren, Hua Zhou*, Ping Wei \\ College of Biotechnology and Pharmaceutical Engineering, Nanjing University of Technology, Nanjing 210009, Jiangsu, China
}

\section{A R T I C L E I N F O}

\section{Article history:}

Received 9 July 2013

Accepted 2 September 2013

Published 20 December 2013

\section{Keywords:}

Lipase

Macroporous resin

Immobilization

Phytosterol ester

Trehalose

\begin{abstract}
A B S T R A C T
Lipase-catalyzed synthesis of phytosterol esters has the advantages of mild reaction conditions and high product purity and yield. However, the activity and stability of enzymes in a non-aqueous phase are generally lower than in an aqueous phase. In this study, a highly efficient synthesis of phytosterol esters was established by using immobilized lipase on a macroporous resin as the catalyst and adding the analogues of lactose during the enzyme catalyzed reaction. In order to facilitate the application of the esterification of phytosterol, the lipases and solvents were screened and the conditions were optimized. In addition, the quantity and type of carbohydrates were investigated, which indicated that immobilized Candida rugosa lipase on NKA (NKA-CRL) was the best catalyst. With a molar ratio of lauric acid to phytosterol of 2, 7.5\% enzyme protein added and the reaction carried out at $40{ }^{\circ} \mathrm{C}$ in $n$-hexane, the esterification rate reached $96.6 \%$ after $10 \mathrm{~h}$, and the esterification rate was still above $85.0 \%$ after six recycles.
\end{abstract}

(C) 2013, Dalian Institute of Chemical Physics, Chinese Academy of Sciences. Published by Elsevier B.V. All rights reserved.

\section{Introduction}

Phytosterol, which is a mixture of $\beta$-sitosterol, stigmasterol, and campesterol, is a natural medically active substance extracted from plants. Due to a similar chemical structure to cholesterols, phytosterols can effectively reduce the levels of total cholesterols and low density cholesterols in blood [1,2], and they are also anti-viral and can be used for anti-inflammatory fever and preventing cancer. Consequently, there are broad possible applications for phytosterols in the fields of pharmaceuticals, health products, and cosmetics [3]. However, poor solubility in water and fat drastically limits these applications of phytosterols [4]. Phytosterol esters, made by the esterification of the C-3 hydroxy of phytosterol with fatty acids, have the advantage of better lipid solubility than phytosterols. More importantly, they can be hydrolyzed in the human body and possess the same physiological activity as phytosterols [5].
Phytosterol esters are mainly synthesized by chemical and enzymatic methods. The latter has the advantages of mild conditions, high conversion rate, and no side reactions [6-8]. Lipase-catalyzed esterification and transesterification are generally carried out in a non-aqueous phase, mainly in an organic solvent. In general, the catalytic activity and stability of enzymes are lower than those in an aqueous phase, leading to low esterification rates, long reaction time, and high costs of the enzymatic synthesis of phytostanol esters $[9,10]$. Immobilization can increase resistance to the organic solvent as well as the catalytic efficiency of an enzyme in the non-aqueous phase and also decrease costs by the reuse of the catalyst $[11,12]$. Yao et al. [13] employed an immobilized lipase, Novozyme 435, to catalyze the esterification of phytostanols and lauric acid in hexane, but the esterification rate was only 36.5\%. Zheng et al. [14] immobilized Candida rugosa lipase on the modified surface of magnetic nanoparticles, and the yield of phytosterol ester

\footnotetext{
*Corresponding author. Tel: +86-25-58139916; E-mail: zhouhua@njut.edu.cn This work was supported by the National Basic Research Program of China (973 Program, 2009CB724706). DOI: 10.1016/S1872-2067(12)60700-1 | http://www.sciencedirect.com/science/journal/18722067 | Chin. J. Catal., Vol. 34, No. 12, December 2013
} 
was increased to $93.5 \%$. More important, the esterification rate was maintained at about $80 \%$ after 5 recycles. However, the preparation of the immobilized enzyme was complicated, and its stability can be further enhanced.

It is widely recognized that trace water is prerequisite to provide the enzyme molecules with the flexibility for enzymatic catalysis in a non-aqueous phase, so covalent modification of the lipase surface by attaching amphiphilic macromolecules has been performed by some researchers to improve enzymatic activity and stability in non-aqueous phases $[15,16]$. Carbohydrates, which contain plentiful hydroxyls and have stronger water-holding capacity as well as biocompatibility with enzymes, are often used to decorate the free enzyme [17]. However, the harsh reaction conditions needed and the changes in the structure of the enzyme molecules caused irreversible loss of enzymatic activity during the modifying processes. In this study, common macroporous resins used in industrial applications were used for lipase adsorption, and the replenishment of carbohydrates during the esterification of phytostanols catalyzed by the immobilized lipase in a non-aqueous phase was used to further improve the catalytic activity of lipase and establish a simple and efficient method for the synthesis of phytosterol esters.

\section{Experimental}

\subsection{Preparation of immobilized lipase}

Macroporous resins, NKA and AB-8, provided by Nankai University Chemical Plant, and LX-1000HA, produced by Lanxiao Science and Technology Ltd., were pretreated according to the instructions provided by the suppliers. An amount of lipase, either Candida rugosa lipase (CRL, Sigma-Aldrich), porcine pancreas lipase (PPL, Sigma-Aldrich) or Candida sp. 99-125 lipase (CSL, Beijing CTA New Century Biotechnology Co., Ltd.) was dissolved in a phosphate buffer of $\mathrm{pH} 5.0$ by stirring at $4{ }^{\circ} \mathrm{C}$ for 30 min to obtain an enzyme solution with the concentration of $4 \mathrm{mg} / \mathrm{ml}$. Then, the solution was centrifuged at $4{ }^{\circ} \mathrm{C}$ and 1000 $\mathrm{r} / \mathrm{min}$ for $5 \mathrm{~min}$. The supernatant was mixed with $0.1 \mathrm{~g}$ of the pretreated macroporous resin. After adsorption at $30^{\circ} \mathrm{C}$ for $2 \mathrm{~h}$, the immobilized lipase was collected by suction filtration and washed using $5 \mathrm{ml}$ of the phosphate buffer of $\mathrm{pH}$ 5.0. After that, the immobilized lipase was immersed in a small amount of the phosphate buffer of pH 7.5 for $1 \mathrm{~min}$, followed by suction filtration again. Finally, the immobilized lipase was dried by vacuum drying at $30^{\circ} \mathrm{C}$ for $48 \mathrm{~h}$, and the conformation of the lipase was adjusted to its optimum using the "pH memorability" of the enzyme. The immobilized lipases were abbreviated according to the type of lipase and support, namely, NKA-CRL, NKA-PPL, NKA-CSL, AB-8-CRL, AB-8-PPL, AB-8-CSL, HA-CRL, HA-PPL, and HA-CSL, respectively.

\subsection{Synthesis of phytosterol esters}

The acyl donor, 0.2-0.8 mmol of lauric acid (AR, Sinopharm Chemical Reagent Co., Ltd.), was mixed with 0.2 mmol of phytosterol (Total content of 92.1\%, consisted of $44.7 \%$ $\beta$-sitosterol, $23.4 \%$ stigmasterol, and $24.0 \%$ campesterol, Zhejiang Davi Biochemistry Co., Ltd.), $2 \mathrm{ml}$ of reaction solvent, and $0.1 \mathrm{~g}$ of NKA-CRL or another kind of lipase in a flask. Deionized water $(4 \mu \mathrm{l})$ or a sugar solution was added, and the whole system was placed in a shaker controlled at different temperatures for $2 \mathrm{~h}$. Then, $0.5 \mathrm{~g}$ of $4 \AA$ molecular sieve was added to absorb excessive water. After the reaction, the immobilized lipase was collected by filtration, and the filtrate was further treated through a filter membrane of $0.22 \mu \mathrm{m}$ before analysis by a gas chromatograph (Agilent 6890) using a DB-5HT capillary column $(15 \mathrm{~m} \times 0.32 \mathrm{~mm} \times 0.10 \mu \mathrm{m})$ and $\mathrm{N}_{2}$ as the carrier gas. The column temperature was held at $180{ }^{\circ} \mathrm{C}$ for $1 \mathrm{~min}$, heated to $350^{\circ} \mathrm{C}$ at $10^{\circ} \mathrm{C} / \mathrm{min}$, and maintained for 3 min. The FID detector and injector temperatures were both set to $350{ }^{\circ} \mathrm{C}$. The phytosterol content was obtained by the peak area normalization method. The esterification rate was calculated by esterification rate $=\left(1-\left(W_{2} / W_{1}\right)\right) \times 100 \%$, where $W_{1}$ and $W_{2}$ were the contents of phytosterol before and after the esterification reaction, respectively.

\section{Results and discussion}

\subsection{Effect of reaction solvent}

The reactions were carried out with $0.1 \mathrm{~g}$ of NKA-CRL and 4 $\mu \mathrm{l}$ of deionized water at $40{ }^{\circ} \mathrm{C}$ for $16 \mathrm{~h}$, with the molar ratio of lauric acid to phytosterol as 2 , in $2 \mathrm{ml}$ of different organic solvents. The esterification rates are shown in Fig. 1.

It was found in our previous work that phytosterol is completely dissolved in dichloromethane and its solubility in weakly polar solvents, such as 2-methyl-2-butanol (2M2B) and methyl tert-butyl ether (MTBE), was higher than in toluene and $n$-hexane, which are both non-polar solvents. In addition, the immobilized lipase on the macroporous resin floated on the surface of dichloromethane, which reduced enzyme contact with the substrate. Moreover, the hydrated layer and the essential water of the lipase may both be lost in dichloromethane due to its low hydrophobic constant $(\log P=1.25)$. For the same reason, the catalytic activity of immobilized lipases in $2 \mathrm{M} 2 \mathrm{~B}$ $(\log P=1.00)$ and MTBE $(\log P=1.19)$ was not ideal as well.

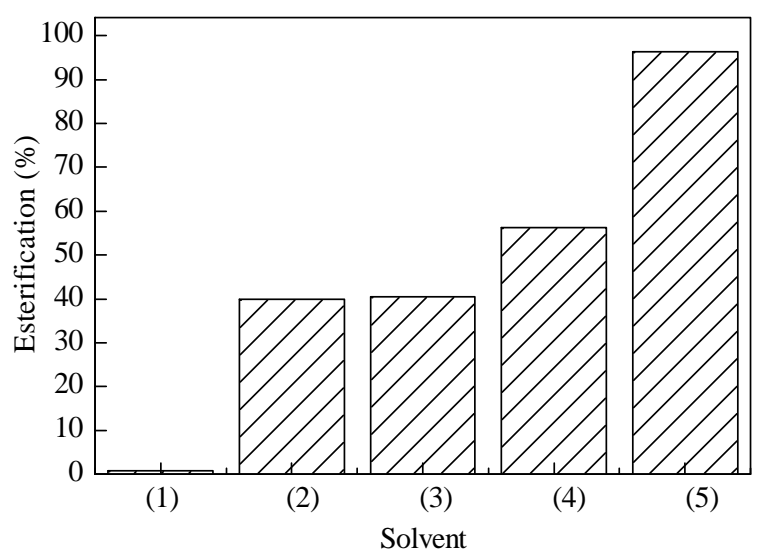

Fig. 1. Effect of solvent on the esterification of phytosterols acetate. (1) Dichloromethane; (2) Toluene; (3) 2-Methyl-2-butanol; (4) Methyl tertbutyl ether; (5) $n$-Hexane. 
Table 1

Immobilization of CRL on different macroporous resins.

\begin{tabular}{lcccc}
\hline $\begin{array}{l}\text { Immobilized } \\
\text { lipase }\end{array}$ & $\begin{array}{c}\text { Loading amount } \\
\text { of protein } \\
(\mathrm{mg} / \mathrm{g})\end{array}$ & $\begin{array}{c}\text { Protein } \\
\text { recovery } \\
(\%)\end{array}$ & $\begin{array}{c}\text { Specific } \\
\text { enzyme } \\
\text { activity (U/g) }\end{array}$ & $\begin{array}{c}\text { Enzyme } \\
\text { activity } \\
\text { recovery (\%) }\end{array}$ \\
\hline NKA-CRL & 4.8 & 84.0 & 83.0 & 81.5 \\
AB-8-CRL & 4.5 & 80.0 & 75.5 & 74.0 \\
HA-CRL & 1.3 & 22.6 & 28.1 & 21.2 \\
\hline
\end{tabular}

Indeed, phytosterol is neither completely dissolved in toluene $(\log P=2.39)$ nor $n$-hexane $(\log P=3.87)$, but it continues to be dissolved into the solvent as previously dissolved phytosterol is esterified and catalyzed by lipase. As a result, there was no solid substrate in the later stage of the enzymatic reaction. Because $\log P$ of $n$-hexane is closer to 4 , which is the optimum value for lipase catalysis [9], it rather than toluene or $n$-hexane was chosen as the solvent.

\subsection{Effect of support and lipase}

With CRL as the catalyst, under the same conditions, the results of lipase immobilization on different macroporous resins are shown in Table 1. Because the lipase and support were both varied, different immobilized lipases with equal enzyme protein content were employed as catalyst to synthesize phytosterol esters. The results are shown in Table 2.

The enzyme activity recovery and protein recovery are reported as the percentages of enzyme activity and protein content of the immobilized enzyme of that of the free enzyme. The enzyme activity recovery and the protein recovery of HA-CRL were both obviously less than those of NKA-CRL and AB-8-CRL. This was mainly because the specific surface area of LX-1000HA was only $170 \mathrm{~m}^{2} / \mathrm{g}$, while those of NKA and AB-8 were 590 and $520 \mathrm{~m}^{2} / \mathrm{g}$, respectively. According to another literature report, a hydrophobic support can further improve the activity and stability of immobilized lipase [18]. AB-8 and LX-1000HA were both weakly polar, but NKA was a typical nonpolar support. As shown in Table 1, if only the immobilized results were considered, NKA would be the best choice.

As shown in Table 2, among the three lipases used, the esterification rates of phytosterol catalyzed by CRL were better than PPL and CSL in both the free and immobilized forms, and were even better than Novozyme 435, which was already an immobilized lipase. Thus, CRL is more suitable for the catalytic synthesis of phytosterol ester. After immobilization, the activity of CRL to catalyze the syntheses of phytosterol esters was all improved by different degrees. Among them, the esterification

Table 2

Activity of immobilized lipases in the esterification of phytosterol.

\begin{tabular}{lc|lc}
\hline Lipase & Esterification (\%) & Lipase & Esterification (\%) \\
\hline NKA-CRL & 96.6 & HA-PPL & 28.9 \\
NKA-PPL & 32.6 & HA-CSL & 21.2 \\
NKA-CSL & 26.8 & Novozyme 435 & 32.4 \\
AB-8-CRL & 85.3 & CRL & 42.7 \\
AB-8-PPL & 30.2 & PPL & 29.3 \\
AB-8-CSL & 23.4 & CSL & 15.6 \\
HA-CRL & 73.5 & & \\
\hline
\end{tabular}

rate of phytosterol catalyzed by NKA-CRL reached $96.6 \%$ in the organic media. Therefore, NKA-CRL was chosen as the catalyst in the following experiments.

\subsection{Effect of reaction temperature and substrate ratio}

On the basis of research above, the reactions were carried out using the molar ratio of lauric acid to phytosterol from 1 to 4 and at $30-50{ }^{\circ} \mathrm{C}$. The results are shown in Fig. 2.

The reaction temperature has a large influence. Raising the temperature reduces the viscosity of the reaction liquid and decreases mass transfer resistance, but the high temperature can deactivate the enzyme. As shown in Fig. 2, the optimal temperature was $40^{\circ} \mathrm{C}$ for this reaction system. In principle, there is already complete esterification when the mole ratio of lauric acid to phytosterol is 1 . However, increasing the acyl donor would promote the enzyme-catalyzed reaction into the direction of ester synthesis, and the residual acid can be reused after separation from the reaction system. As shown in Fig. 2, when the mole ratio of lauric acid to phytosterol was increased form 1 to 2, the esterification rate showed significant improvement. However, the esterification rate decreased when the ratio was more than 3 . Too much acid inhibits the lipase and makes the separation and purification of products difficult. Therefore, the mole ratio of lauric acid to phytosterol was 2 in the following experiments.

\subsection{Effect of different additives}

On the basis of the above research, the effect of adding different carbohydrates, such as lactose, trehalose, maltose, and sucrose (all at $5 \%$ of the quantity of enzyme protein), during the catalytic process on the esterification of phytosterol was investigated. The results are shown in Fig. 3.

The CRL purchased from Sigma contained 38\% of lactose, and the removal of the lactose always led to decreased catalytic activity and stability of CRL [17]. It was found in our previous work that lactose, which is a micromolecular disaccharide, cannot be adsorbed by macroporous resins. This means that

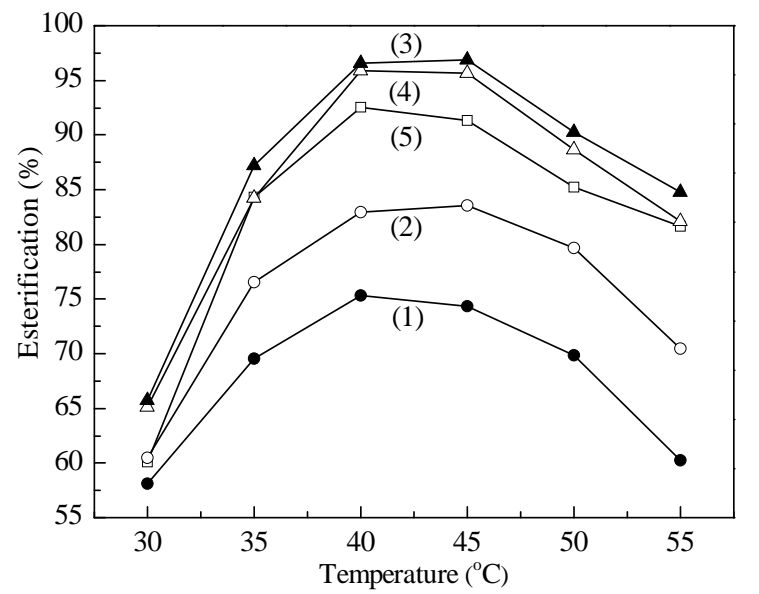

Fig. 2. Effects of temperature and molar ratio of lauric acid to phytosterol on the esterification of phytosterol. (1) 1; (2) 1.5; (3) 2; (4) 3; (5) 4 . 


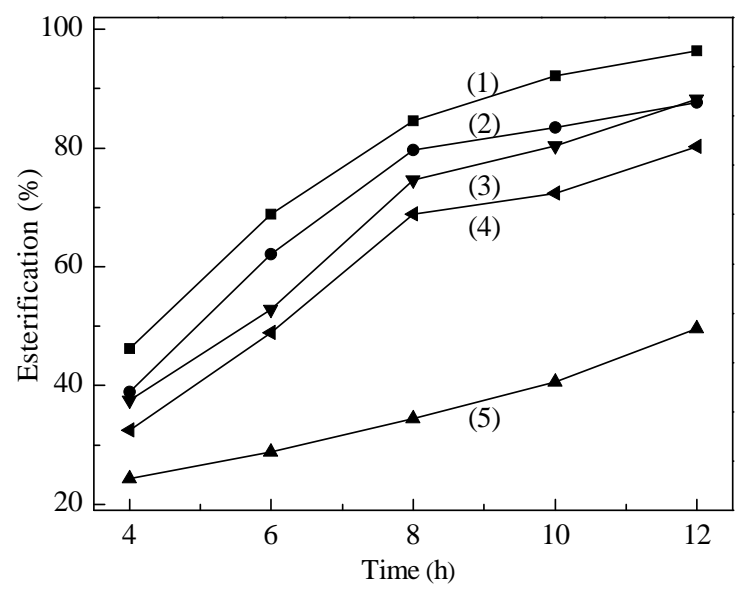

Fig. 3. Effect of additive on the esterification of phytosterol. (1) Trehalose; (2) Maltose; (3) Lactose; (4) Without additive; (5) Sucrose.

CRL would lose the protection of the carbohydrate when the lipase was immobilized. In the reaction system of this study, the aqueous solution of lactose or its analogue was attached to a site-directed area of the lipase surface, which was generally hydrophilic and far from the active site due to the expulsion from the hydrophobic solvent (with a high $\log P$ value). As a result, the immobilized lipase was protected by the additive. Figure 3 indicates that although sucrose gave a negative effect, the other additives all promoted the esterification of phytosterol. The highest promotion effect was produced by trehalose. The carbohydrates chosen as additives in this study were all the analogues of lactose, which possessed almost the same chemical structure and water binding capacity, but have no homogeneous effects. Trehalose, however, can form a glassy state in and around the enzyme molecules, especially near the active sites of the enzymes [19], so that the higher activity and stability of the lipase were preserved in the non-aqueous phase.

\subsection{Effect of additive dosage}

On the basis of the research above, the reactions were carried out with the dosage of trehalose varying from $2.5 \%$ to $10 \%$ of the quantity of the enzyme protein. The results are shown in Fig. 4.

The enzyme has to combine with a small amount of water in order to meet the requirement for conformational changes during the catalytic process in a non-aqueous phase. The water binding capacity of the native lipase is normally deficient, but it can be modified by adding an aqueous solution of carbohydrate with different concentrations. If the amount of carbohydrate was insufficient, the catalytic ability of the lipase would be limited to be low because of a shortage of combined water. In contrast, the esterification rate can be decreased by the hydrolysis of phytosterol esters when too much water was combined onto the lipase molecule. In addition, excess carbohydrates can occupy the limited inner space of the porous support and increase the resistance to mass and energy transfer during the catalytic process of the immobilized lipase. As shown in Fig. 4, the addi-

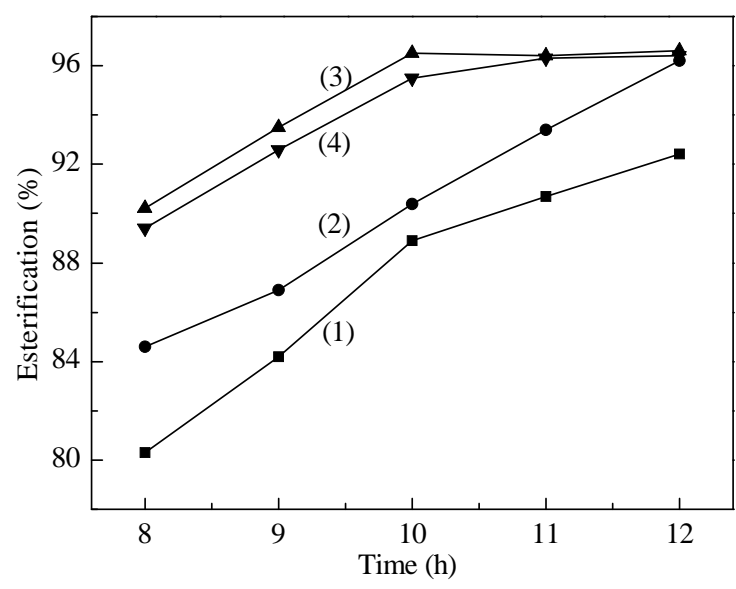

Fig. 4. Effect of the amount of trehalose on the esterification of phytosterol. (1) $2.5 \%$; (2) 5\%; (3) 7.5\%; (4) $10 \%$.

tion of trehalose in only $7.5 \%$ of the total quantity of enzyme protein reduced the time to reach $96 \%$ esterification from $16 \mathrm{~h}$ to $10 \mathrm{~h}$.

\subsection{Stability of the immobilized lipase}

Under the optimum conditions, NKA-CRL was employed to catalyze the esterification of phytosterol. The results with and without the addition of trehalose are both shown in Fig. 5.

Because of the insolubility of lipase in the organic solvent, leakage of physically adsorbed lipase is unlikely in this reaction system, which resulted in $81.5 \%$ esterification rate after five recycles. However, there is inevitable diminution in the catalytic activity of lipase if it was incubated in an organic medium for a long time. As described above, the aqueous solution of trehalose can be attached to the site-directed area of the hydrophilic surface, leaving the active site of the lipase to the hydrophobic solvent and substrates in this hydrophobic system. Consequently, building a large hydrated layer around the hydrophilic surface of lipase can segregate the enzyme molecule from the organic solvent and make the catalytic activity and stability of the immobilized lipase outstanding. With the addition of treha-

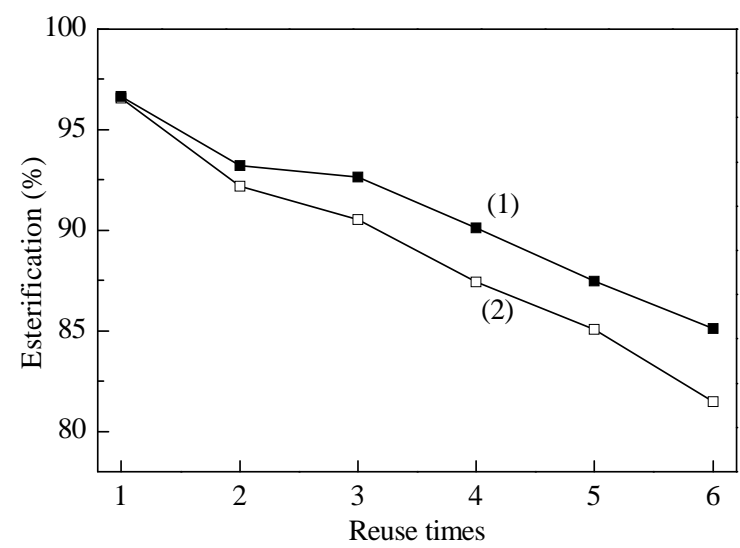

Fig. 5. Stability of NKA-CRL with trehalose(1) and without additive(2). The maximum reaction time with trehalose and without additive was $10 \mathrm{~h}$ and $16 \mathrm{~h}$, respectively. 


\title{
Graphical Abstract
}

Chin. J. Catal., 2013, 34: 2255-2262 doi: 10.1016/S1872-2067(12)60700-1

\section{Synthesis of phytosterol ester catalyzed by immobilized lipase in organic media}

Zhenhua Jiang, Min Yu, Liwei Ren, Hua Zhou*, Ping Wei Nanjing University of Technology

The high-efficiency esterification of phytosterols was catalyzed by immobilized lipase in organic media and supplemented by the aqueous solution of trehalose during the enzymatic process.

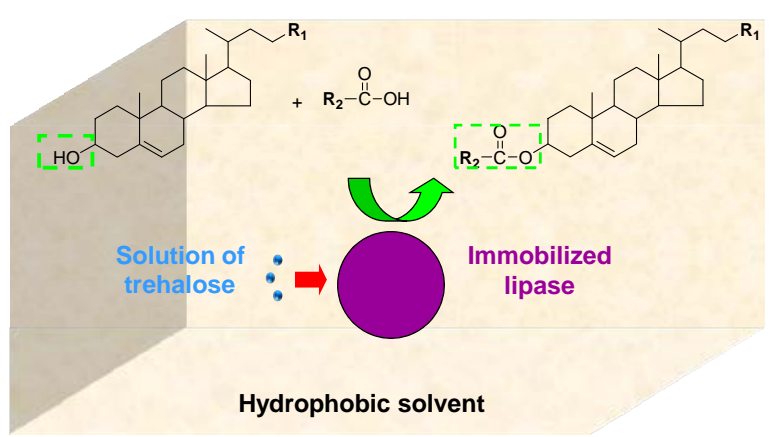

lose, the esterification rate was still $85.1 \%$ after five recycles. Moreover, it could return to $96.5 \%$ when the reaction time was prolonged to $14 \mathrm{~h}$. The probable reason for the slightly lower activity of the enzyme with recycling was the unavoidable decrease in the amount of immobilized lipase in the continuous operation. It is noted that because only $4 \mu \mathrm{l}$ of the sugar solution was added to $2 \mathrm{ml}$ of the reaction system, this method almost does not have any increase in production cost. In principle, this method can also be used in other enzymatic processes in a non-aqueous phase.

\section{Conclusions}

The method of adding an aqueous solution of carbohydrate during an enzymatic process in an organic medium was used to improve the activity and stability of the enzyme. On the basis of this strategy, phytosterol esters were successfully synthesized in $n$-hexane when catalyzed by immobilized CRL on the macroporous resin NKA. The many advantages of the process, such as high esterification rate, high enzyme stability, and no toxic byproduct, give it good potential for industrial applications.

\section{References}

[1] Weber N, Weitkamp P, Mukherjee K D. Food Res Int, 2002, 35: 177

[2] Delaney B, Stevens L A, Schmelzer W, Haworth J, McCurry S, Hilfinger J M, Kim J S, Tsume Y, Amidon G L, Kritchevsky D. J Nutr Biochem, 2004, 15: 289
[3] Choi Y H, Kong K R, Kim Y A, Jung K O, Kil J H, Rhee S H, Park K Y. Int J Oncol, 2003, 23: 1657

[4] Nashed B, Yeganeh B, HayGlass K T, Moghadasian M H. J Nutr, 2005, 135: 2438

[5] Okoli C 0, Akah P A. Pharmacol Biochem Behav, 2004, 79: 473

[6] Kim B H, Akoh C C. Food Chem, 2007, 102: 336

[7] Villeneuve P, Turon F, Caro Y, Escoffier R, Barea B, Barouh B, Lago R, Piombo G, Pina M. Enzyme Microb Technol, 2005, 37: 150

[8] Vu P L, Shin J A, Lim C H, Lee K T. Food Res Int, 2004, 37: 175

[9] He Q, Xu Y, Teng Y, Wang D. Chin J Catal (贺芹, 徐岩, 滕云, 王栋. 催化学报), 2008, 29: 41

[10] Shan H X, Lu Y, Li Z J, Li M, Cai Y, Sun X L, Zhang Y Z. Chin J Catal (单海霞, 陆杨, 李在均, 李明, 蔡燕, 孙秀兰, 张银志. 催化学报), 2010, 31: 289

[11] Zheng M M, Lu Y, Huang F H, Wang L, Guo P M, Feng Y Q Deng Q C. J Agric Food Chem, 2013, 61: 231

[12] Gao Y, Tan T W, Nie K L, Wang F. Chin J Biotechnol (高阳, 谭天伟, 聂开立, 王芳. 生物工程学报), 2006, 22: 114

[13] Yao X L, Huang Q Chen M B. Food Res Develop (姚晓玲, 黄琴, 陈 茂涁. 食品研究与开发), 2007, 28(7): 15

[14] Zheng M M, Dong L, Lu Y, Guo P M, Deng Q C, Li W L, Feng Y Q, Huang F H.J Mol Catal B, 2012, 74: 16

[15] Basri M, Ampon K, Yunus W M Z W, Razak C N A, Salleh B. J Chem Technol Biotechnol, 1994, 59: 37

[16] Hernaiz M J, Sanchez-Montero J M, Sinisterra J V. Biotechnol Lett, 1997, 19: 303

[17] de la Casa R M, Guisan J M, Sanchez-Montero J M, Sinisterra J V. Enzyme Microbial Technol, 2002, 30: 30

[18] Serra E, Diez E, Diaz I, Blanco R M. Microporous Mesoporous Mater, 2010, 132: 487

[19] Yang J C, Dong S, Yang X M. J Chem Ind Eng (China) (杨基础, 董蔡, 杨小民. 化工学报), 2000, 51: 193

\section{有机相中固定化脂肪酶催化合成植物甾醇酯}

\author{
蒋振华, 于 敏, 任立伟, 周 华*, 韦 萍 \\ 南京工业大学生物与制药工程学院, 江苏南京210009
}

摘要: 酶法合成植物甾醇酯具有反应条件温和、产物纯度和产量高等优点, 但非水相酶催化的活性和稳定性普遍较低. 本文以大 孔树脂固定化脂肪酶为催化剂, 并在催化过程中添加乳糖的类似物, 构建了有机相高效合成植物甾醇酯的工艺过程. 以酯化率为 考察指标, 对脂肪酶和反应溶剂进行笁选, 对酯化条件进行优化, 同时考察了糖的种类及添加量对酶催化性能的影响. 结果表明, 
大孔树脂NKA吸附固定化的褶䏢假丝酵母(Candida rugosa)脂肪酶(NKA-CRL)为最适宜的催化剂, 以正己烷为反应介质, 在酸醇 摩尔比为 2 和添加酶蛋白质量 $7.5 \%$ 的海藻糖的条件下, $40{ }^{\circ} \mathrm{C}$ 反应 $10 \mathrm{~h}$, 酯化率达到 $96.6 \%$. 连续 6 次催化后, 植物甾醇的酯化率仍维 持在 $85.0 \%$ 以.

关键词: 脂肪酶; 大孔树脂; 固定化; 植物甾醇酯; 海藻糖

收稿日期: 2013-07-09. 接受日期: 2013-09-02. 出版日期: 2013-12-20.

*通讯联系人. 电话: (025)58139916; 电子信箱: zhouhua@njut.edu.cn 基金来源: 国家重点基础研究发展计划(973计划, 2009CB724706).

本文的英文电子版由Elsevier出版社在ScienceDirect上出版(http://www.sciencedirect.com/science/journal/18722067).

\section{1. 前言}

植物甾醇是一种来源于植物的天然活性物质, 主要 由 $\beta$-谷甾醇、豆甾醇和菜油甾醇等混合组成. 植物甾醇 的化学结构与胆固醇类似, 可有效降低血液中总胆固醇 及低密度胆固醇的含量 ${ }^{[1,2]}$, 并具有抗病毒、消炎退热和 防治癌症等功效, 在医药、保健品和化妆品等领域均具 有广阔的应用前景 ${ }^{[3]}$. 然而, 植物甾醇的脂溶性和水溶 性均较差, 极大地限制了其在上述领域的应用 ${ }^{[4]}$. 植物 甾醇酯是植物甾醇 $\mathrm{C}-3$ 上的羟基与脂肪酸形成的酯类化 合物, 具有良好的脂溶性, 并且可在人体内被水解, 具有 与植物甾醇相同的生理活性 ${ }^{[5]}$.

植物甾醇酯主要通过化学法和酶法合成, 其中酶法 因反应条件温和、转化率高和无副反应等优势而广受研 究者亲睐 ${ }^{[6-8]}$. 脂肪酶催化的酯化或转酯反应一般需要 在非水相, 且主要在有机溶剂中进行. 然而, 有机相游离 酶催化的活性和稳定性普遍较低, 导致目前酶法合成植 物甾醇酯仍存在酯化率低, 反应时间长和生产成本高等 不足 ${ }^{[9,10]}$. 固定化酶可以提高非水相酶催化的效率和酶 对有机溶剂的耐受性, 并且通过酶的重复利用降低生产 成本 ${ }^{[11,12]}$. 姚晓玲等 ${ }^{[13]}$ 在正已烷中使用固定化脂肪酶 Novozyme 435催化合成月桂酸植物甾醇酯, 酯化率仅为 36.5\%. Zheng等 ${ }^{[14]}$ 将褶皱假丝酵母(Candida rugosa)脂 肪酶共价固定化到经过修饰的磁性纳米颗粒的表面, 使 得植物甾醇在有机相中的酯化率增至93.5\%. 更为重要 的是连续进行 5 次催化反应后, 酯化率仍维持在 $80 \%$ 左 右. 但该固定化酶的制备过程较为复杂, 操作稳定性仍 需进一步提高.

酶在非水相催化时需要结合微量的“必需水”以满 足催化过程中酶构象变化的要求. 已有较多的研究将双 亲性大分子化合物共价修饰到脂肪酶的表面, 以提高非 水相酶催化的活性和稳定性 ${ }^{[15,16]}$. 糖类化合物含有大量 的羟基, 具有较强的结合水的能力, 并且与酶分子之间 具有良好的生物相容性, 所以常被用于修饰游离酶 ${ }^{[17]}$. 但由于苛刻的化学反应条件和对酶结构的改变, 修饰过
程往往造成酶活性不可逆的损失. 本文以工业生产中常 用的大孔树脂为载体, 采用简单的物理吸附法固定化脂 肪酶, 并尝试在非水相酶催化过程中补加糖类化合物, 以进一步提高脂肪酶有机相的催化能力, 建立一个简 单、高效的植物甾醇酯合成方法.

\section{2. 实验部分}

\section{1. 固定化脂肪酶的制备}

分别按照供应商提供的方法对大孔树脂 NKA, AB-8 (南开大学化工厂) 和 LX-1000HA (西安蓝晓科技 有限公司)进行预处理. 将适量褶皱假丝酵母脂肪酶 (CRL, Sigma公司)、猪胰脂肪酶 (PPL, Sigma公司)和假 丝酵母99-125脂肪酶 (CSL, 北京凯泰新世纪公司)溶解 在 $\mathrm{pH} 5.0$ 的磷酸盐缓冲液中, $4^{\circ} \mathrm{C}$ 下搅拌 $30 \mathrm{~min}$, 配制成 4 $\mathrm{mg} / \mathrm{ml}$ 的酶溶液, 经 $4{ }^{\circ} \mathrm{C}$ 下 $1000 \mathrm{r} / \mathrm{min}$ 离心 $5 \mathrm{~min}$ 后, 取 5 $\mathrm{ml}$ 上清液与 $0.1 \mathrm{~g}$ 上述载体混合. $30^{\circ} \mathrm{C}$ 吸附 $2 \mathrm{~h}$ 后, 用砂芯 漏斗抽滤提取固定化酶, 并用 $5 \mathrm{ml} \mathrm{pH} 5.0$ 的缓冲液冲洗 固定化酶数次. 用少量 $\mathrm{pH}$ 7.5的磷酸盐缓冲液浸泡固定 化酶 $1 \mathrm{~min}$ 后再次抽滤, 将固定化酶于 $30^{\circ} \mathrm{C}$ 真空干燥 48 $\mathrm{h}$, 利用酶的“pH记忆性” 将脂肪酶的构象调至最适宜催 化的状态. 将以NKA, AB-8和LX-1000HA为载体物理吸 附 CRL, PPL 和 CSL 得到的固定化酶分别简写为 NKA-CRL, NKA-PPL, NKA-CSL, AB-8-CRL,AB-8-PPL, AB-8-CSL, HA-CRL, HA-PPL和HA-CSL.

\section{2. 植物甾醇酯的合成}

以0.2-0.8 mmol月桂酸(分析纯, 国药试剂)为酰基供 体, 与 $0.2 \mathrm{mmol}$ 植物甾醇(总含量 $92.1 \%$, 其中 $\beta$-谷甾醇 $44.7 \%$, 豆甾醇 $23.4 \%$, 菜油甾醇 $24 \%$, 浙江大为药业有限 公司), $2 \mathrm{ml}$ 反应溶剂和 $0.1 \mathrm{~g}$ NKA-CRL或与之酶蛋白含 量相同的其它脂肪酶加至磨口三角瓶中, 混匀后添加 4 $\mu \mathrm{l}$ 去离子水或不同浓度的糖溶液, 于不同温度下在恒温 摇床中反应 $2 \mathrm{~h}$ 后, 加入 $0.5 \mathrm{~g}$ 的 $4 \mathrm{~A}$ 分子篮以去除反应生 成的过量水. 反应结束后, 过滤回收固定化脂肪酶, 滤液 经 $0.22 \mu \mathrm{m}$ 的有机相滤头过滤后, 进气相色谱仪(Agilent 6890)测定植物甾醇的转化率. 色谱条件如下: 载气为 
$\mathrm{N}_{2}$; 检测器为 $\mathrm{FID}, 350{ }^{\circ} \mathrm{C}$; 气化室 $350^{\circ} \mathrm{C}$; 色谱柱为 DB-5HT $(15 \mathrm{~m} \times 0.32 \mathrm{~mm} \times 0.10 \mu \mathrm{m})$; 柱室温度 $180^{\circ} \mathrm{C}$ 维持 $1 \mathrm{~min}$, 以 $10^{\circ} \mathrm{C} / \mathrm{min}$ 升温至 $350^{\circ} \mathrm{C}$ 并维持 $3 \mathrm{~min}$. 通 过峰面积归一化法计算植物甾醇含量, 酯化率按公式酯 化率 $=\left(1-\left(W_{2} / W_{1}\right)\right) \times 100 \%$ 计算, 式中 $W_{1}$ 为酯化反应前 体系中植物甾醇含量, $W_{2}$ 为酯化反应后体系中植物甾醇 含量.

\section{3. 结果与讨论}

\section{1. 反应溶剂的影响}

以 $2 \mathrm{ml}$ 不同种类的有机溶剂为反应介质, 维持月桂 酸与植物甾醇摩尔比为 2 , 以 $0.1 \mathrm{~g}$ 的NKA-CRL为催化剂, 以 $4 \mu \mathrm{l}$ 去离子水为添加剂, $40{ }^{\circ} \mathrm{C} 反$ 应 $16 \mathrm{~h}$ 后, 酯化率如图 1所示.

研究发现, 植物甾醇在二氯甲烷中的溶解度较大, 而在2-甲基-2-丁醇(2M2B)和甲基叔丁基醚(MTBE)等弱 极性溶剂中的溶解度也高于甲苯和正己烷等非极性有 机溶剂. 但实验中发现干燥后的大孔树脂固定化脂肪酶 漂浮于二氯甲烷的液面, 极大地降低了固定化酶与底物 接触的几率. 此外, 二氯甲烷的疏水常数 $(\log P=1.25)$ 较 低, 可破坏脂肪酶的水化层, 剥夺酶催化微量的“必需 水”. 同理, 固定化脂肪酶在2M2B $(\log P=1.00)$ 和MTBE $(\log P=1.19)$ 中的催化效果也并不理想. 所加入的植物 甾醇虽然不能完全溶解于甲苯 $(\log P=2.39)$ 和正己烷 $(\log P=3.87)$, 但随着溶解与反应的动态平衡, 植物甾醇 不断溶解于溶剂并被脂肪酶催化, 后期的反应液中已无 底物固体存在. 正已烷相比于甲苯更接近脂肪酶对反应 溶剂疏水性的要求 $(\text { 最适 } \log P \approx 4)^{[9]}$, 因此在以下研究中 选择正已烷为反应溶剂.

\section{2. 载体与脂肪酶的影响}

以CRL为例, 相同条件下不同大孔树脂对脂肪酶的 固定化效果如表1所列. 由于脂肪酶及载体的种类均不 尽相同, 分别以酶蛋白含量相等的不同种类脂肪酶为催 化剂合成植物甾醇酯, 结果如表2所列.

酶活力回收率和酶蛋白回收率分别为得到的固定 化酶的酶活力和所装载的酶蛋白量与固定化时所投入 游离酶的酶活力和酶蛋白总量的百分比. HA-CRL的酶 活力和酶蛋白回收率均明显小于 NKA-CRL 和 AB-8-CRL, 这主要是因为LX-1000HA的比表面仅为 170 $\mathrm{m}^{2} / \mathrm{g}$, 而 NKA和AB-8的比表面积可分别高达 590 和 520 $\mathrm{m}^{2} / \mathrm{g}$. 据文献[18]报道, 疏水性的载体可进一步提高固定 化脂肪酶的催化活性和稳定性. AB-8和LX-1000HA均
为弱极性载体, NKA则为非极性载体. 如表1所示, 如果 仅以固定化效果为依据, NKA为最适宜的固定化载体.

如表2所列, 对于游离和固定化形式的三种脂肪酶, 均是CRL催化合成植物甾醇酯的效果好于同种形式的 PPL和CSL. Novozyme 435为已固定化的商品脂肪酶, 游离CRL 所催化的反应的酯化率已经高于 Novozyme 435, 说明CRL较为适合用于催化合成植物甾醇酯, 而经 固定化后, CRL催化合成植物甾醇酯的能力仍有不同程 度的提升. 其中, NKA-CRL有机相催化植物甾醇的酯化 率已达到96.6\%. 说明即使在酶蛋白含量相等的条件下, 依然是以NKA为载体的固定化酶有机相催化合成植物 甾醇酯的效果最好. 因此, 以下研究均选择NKA-CRL为 催化剂.

\section{3. 底物比与温度的影响}

在上述研究的基础上, 在酸醇摩尔比为 1-4的范围 内, 分别在 $30-55^{\circ} \mathrm{C}$ 条件下进行反应, 结果如图 2 . 反应 温度对酶催化活性具有较大的影响, 升高温度可以降低 反应液的黏度, 减小传质阻力, 但温度过高可能导致酶 变性失活. 如图 2 所示, 反应体系的最适温度为 $40^{\circ} \mathrm{C}$. 理论上, 月桂酸和植物甾醇摩尔比为 1 时即可以完全酯 化. 但增加酰基供体的用量可推动酶催化反应向酯合成 方向进行, 并且剩余的脂肪酸经分离后仍可被重复利用. 由图2可知, 酸醇摩尔比由1增加到2, 酯化率有明显提高. 而进一步增加酸醇摩尔比, 酯化率则有所下降. 这主要 是过多的酸可能会抑制脂肪酶活性并且增加产物分离 提纯的困度. 因此, 以下研究均在酸醇摩尔比为 2 的条件 下进行.

\section{4. 不同种类糖类化合物的添加效果}

在上述研究基础上, 考察了在催化过程中添加不同 种类的糖类化合物(乳糖、海藻糖、麦芽糖、蔗糖, 添加 量为酶蛋白质量的5\%)对酯化效果的影响. 结果如图3 所示. Sigma公司的CRL中含有38\%的乳糖, 文献[17]证 明, 当除去这部分乳糖后, CRL的催化活性和热稳定性 都会有所降低. 研究中发现, 大孔树脂均不会吸附乳糖 这种小分子二糖, 即CRL被固定化后实际已失去了对糖 的保护. 本文所用反应体系中, 疏水性的有机溶剂可驱 使微量的乳糖类似物的水溶液定向结合到脂肪酶表面 背向活性位点的亲水性区域, 重新对脂肪酶进行保护. 由图3所示, 海藻糖对酯化率的提升效果最为显著, 添加 麦芽糖与乳糖具有相类似的促进效果, 而蔗糖的添加反 而具有一定的抑制作用. 研究中所选用的糖均为乳糖的 类似物, 与各添加剂差异并不大的化学结构和结合水能 
力相比, 其作用效果却迥然不同. 文献[19]证明, 海藻糖 可以紧密包裹在酶分子周围, 甚至可以填充在酶蛋白分 子的空间结构内, 并形成更为稳定的玻璃态. 海藻糖的 上述特性可能更有助于提高非水相酶催化的活性和稳 定性.

\section{5. 糖添加量对反应的影响}

在上述研究的基础上, 控制海藻糖的添加量为酶蛋 白质量的 2.5\%-10\%, 各条件的酯化结果如图4所示. 酶 在非水相催化时必须结合微量的水, 以满足催化过程中 构象变化的要求. 而脂肪酶自身结合水的能力相对有 限, 加入不同浓度的糖溶液可以调节脂肪酶结合水的量. 当糖添加量较少时, 脂肪酶结合水量不足, 限制其催化 能力的充分发挥. 相反, 脂肪酶结合过多的水则可能引 发水解逆反应, 导致酯化率降低. 并且, 过多的糖类化合 物可能会占据载体孔道内有限的空间, 增大催化过程中 物质和能量传递的阻力. 由图4所示, 当海藻糖的添加量 为反应体系中酶蛋白总质量的 $7.5 \%$ 时, 可将达到 $96 \%$ 左 右酯化率所需的反应时间由 $16 \mathrm{~h}$ 缩短至 $10 \mathrm{~h}$.

\section{6. 固定化脂肪酶的操作稳定性}

在最优反应条件下, 连续数次以NKA-CRL催化合 成植物甾醇酯, 并与未添加糖类物质时的催化效果进行 比较, 结果如图5所示. 因脂肪酶不溶于疏水性有机溶 剂, 被吸附的酶蛋白几乎不会在催化过程中发生泄漏,
所以以简单的吸附法制备的固定化酶连续6次催化后, 反应的酯化率仍为 $81.5 \%$. 但长时间在有机相中连续催 化, 仍可对酶活性造成较大程度的损伤. 如前所述, 向疏 水性反应体系中添加微量海藻糖水溶液可定向结合到 脂肪酶表面亲水性区域, 将脂肪酶疏水性的活性位点留 给反应溶剂和底物的同时, 在脂肪酶其它亲水性的表面 形成一个更大的水化层, 为脂肪酶提供充足 “必需水”的 同时, 可将脂肪酶与有机溶剂隔离, 对酶进行进一步的 保护. 因此, 在添加海藻糖的条件下, 6 次连续反应后的 酯化率可达到 $85.1 \%$, 并且将第6次反应的时间延长至14 $\mathrm{h}$, 即可恢复至 $96.5 \%$ 的酯化率. 此时, 连续多次催化操 作过程中固定化酶数量不可避免的减少可能是酶表观 活性降低的主要原因. 因所添加的糖溶液的体积非常 小, 此方法几乎不增加生产成本, 并且理论上可应用于 其它非水相催化过程.

\section{4. 结论}

以正己烷为反应溶剂, 以大孔树脂NKA吸附固定化 的脂肪酶CRL为催化剂, 并创造了在有机相催化过程中 添加糖类化合物的水溶液以提高酶催化活性和稳定性 的方法, 成功构建了非水相酶催化合成植物甾醇酯的工 艺过程. 该过程具有酯化率高、固定化酶稳定性好和安 全无副产物等优势, 具有广阔的运用前景. 